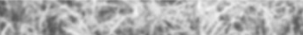

.

\title{
.
}

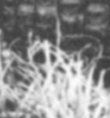

\section{The Chinese Alligator}

\author{
Huang Zhujian
}

The author, who is a scientist at the Zoological Research Institute of the Chinese Academy of Sciences. describes the serious plight of China's endemic alligator. This last summer he was joined by an American research scientist, Dr Myrna E. Watanabe, in a further study of the alligator, and we hope to carry their report in a later issue.

The Chinese alligator Alligator sinensis is unique to China. One of mankind's treasures, it faces extinction. Records of this alligator are found in Chinese literature as far back as three thousand years ago, although it was not scientifically recorded as a separate species until 1870 by Fu Fur (A.A. Fauvel), an officer of the Shanghai Customs. Today it is confined to the middle and lower reaches of the Yangzi river. Because it is rare and endemic it is a First Class Protected Animal.

In a detailed investigation between 1951-1956, Zhu Chengguan and Huang Zhujian described its range as bounded by the Yangzi river in the north, and Huangshan mountain and the region to the north of East Tianmushan mountain in the south, that is, about $30-31^{\circ} \mathrm{N}$ and $118-120^{\circ} \mathrm{E}$. The alligators are found on the valley flats on the Yangzi's left bank, downstream from Pengze to between Anqing and Datong; also at Nanling, Jingxian, Xuancheng, Ningguo, Fanchang, Wuhu, Dangtu and Langxi along the banks of the Qingyi and Shuiyang rivers in the south of Anhui Province; Gaochun and Yixing in Jiangsu Province; to Wuxing and Changxing of Zhejiang Province and the west bank of Taihu lake in the east.

The alligators use caves in the valleys of some of the Yangzi tributaries, as well as pools in the ravines in the hills, and the reeds and bamboo on lake shores and in swamps. But in some areas, building and agricultural development have destroyed their habitat and disturbed their normal activities. Many alligators have moved from the lakes, swamps and ponds in the Jiangnan plain into hill country pools in the upper reaches of the Qingyi and the Zhanghe rivers, which are surrounded, not by reed and bamboo, but by grasses thick Themeda forskalii, Imperata arundinacea, and bottlegrass Setaria viridis - as well as small bushes and forests of small pine. This area is thinly populated, seldom disturbed by man, and rich in food, and alligators have established themselves here in large numbers. At present, they are concentrated mostly in ponds in the hills about $100 \mathrm{~m}$ above sea level, to the north of the mountain system in Southern Anhui; however, a few are still to be found to the north, thinly scattered in the Jiangnan Plain up to the Yangzi river. The present distribution of Alligator sinensis is roughly between 30.6 and $31.6^{\circ} \mathrm{N}$, and 118 and $119.6^{\circ} \mathrm{E}$.

Before 1956, a head count of alligators was made by 123 People's Communes in 11 counties of Anhui Province: Wuhu, Dangtu, Fanchang, Nanling, Jiangxian, Xuancheng, Langxi, Huangde, Ningguo, Qingyang and Wuwei. Since then, alligators have disappeared from some of these; in 1976, in 29 of these communes in 11 counties numbers had declined from 
360 to 120. Anhui Province carried out an investigation studying the alligator's calls and behaviour. They found that typically one male stayed in one cave together with one, two, or even four or five females.

Alligators are clearly decreasing, due not only to loss of habitat, but also because there has been insufficient propaganda and education. People have been allowed to believe that they are harmful to fish farming and duck rearing and have killed them freely, and children, knowing nothing about protecting rare animals, smash the eggs in the breeding season. Moreover, the large quantities of agricultural pesticides and chemical fertilisers used in recent years have destroyed the alligators' food resources and thus menaced their survival. These factors have long eluded a solution.

\section{Moorhens for Malta}

\section{Bill and Sheila Bourne}

The slaughter and capture of hundreds of millions of migrating north European birds in the Mediterranean region have long been a major conservation problem. The worst havoc is in Malta, which subscribes to none of the bird protection conventions, and where the main recreation is to shoot anything large enough to stuff, and to catch anything smaller and put it in a cage.

During the 1980 conference of the European Continental Section of ICBP (the International Council for Bird Preservation) a few of us walked up on to a bare headland one fine morning. The countryside echoed to the song of finches, but only sparrows could be seen because the finches were sitting in little cages set out around clap-nets so that the lonely birds could call their relatives down to join them in captivity. Within one square mile there must have been hundreds of trapping sites, of which about a quarter were in use. Many local people, we were told to take their holidays at this season to go bird-catching. Later at an early Sunday morning market in Valletta we saw dozens of call birds crammed into small cages piled under sacks on the ground and in the backs of vans. The birds for sale included over 500 linnets, which sell for about $£ M 1$ each, serins ( $£ M 2$ ), several hundred chaffinches and bramblings ( $£ M 2-3$ ), goldfinches (£M5-6), greenfinches (£M10) and occasional haw finches $(\boldsymbol{E} M 20-30)$. On a market stall were dozens of starlings, sky and calandra larks, collared doves and quail, and probably also in the vans golden plover, which fetch high prices. Prices were said to be twice as high at other times of year, attracting illegal imports from Sicily and Tunisia, and leading to increased trapping there.

For the larger species the treatment is different. In the past the whole countryside was continually quartered by shooters. At the best wood, at Buskett in the centre of the island, now declared a reserve, we were told how earlier in the autumn hundreds of hunters would wait at dusk to shoot the birds of prey as they flew in to roost. In one evening last year this accounted for over 40 honey buzzards, several harriers and kestrels, two kites, a peregrine, a red-footed falcon, and one or two Eleonora's falcons. We

CALL BIRDS

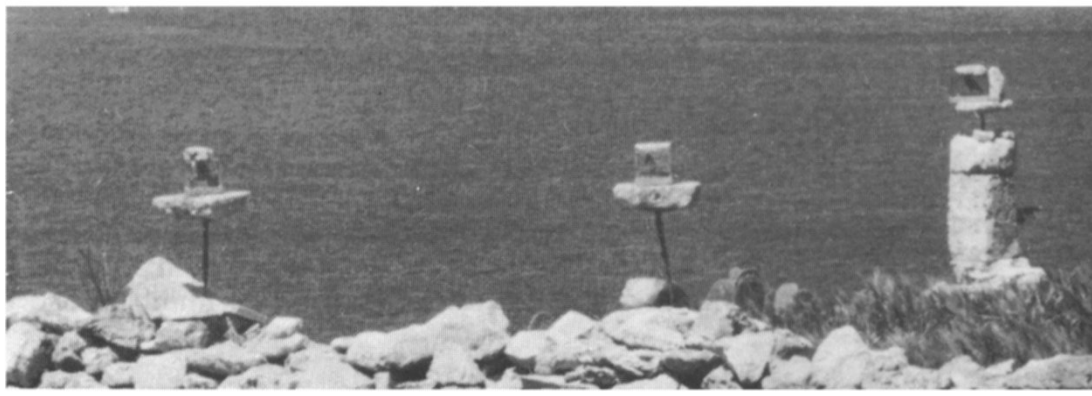

